\title{
The Euro Crisis and the Question of Solidarity in the European Union: Disclosures and Manifestations in the European Press
}

\author{
Maria Kontochristou ${ }^{1} \&$ Evi Mascha ${ }^{2}$ \\ ${ }^{1}$ School of Social Sciences, Hellenic Open University, Patras, Greece \\ ${ }^{2}$ Asylum Service, Ministry of Public Order and Citizen Protection, Greece \\ Correspondence: Maria Kontochristou, School of Social Sciences, Hellenic Open University, 57-59 Bouboulinas \\ Street, Patras 26222, Greece. Tel: 30-2610-367-456. E-mail:mkontochristou@eap.gr
}

Received: March 23, 2014, 2014 Accepted: Mary 23, 2014 Online Published: May 27, 2014

doi:10.5539/res.v6n2p50

URL: http://dx.doi.org/10.5539/res.v6n2p50

\begin{abstract}
Solidarity lies at the very heart of European society as a value and a guiding principle for numerous policies. Since the eurozone was created, solidarity has functioned as one of the political parameters necessary for sharing responsibility for financial implications and austerity measures. Behind every financial assistance, measure and subsidy lies the solidarity principle, which holds each member state responsible. The article discusses the concept of solidarity, mentions its lack or omission and addresses the attitudes in the debate on solidarity portrayed in the press. More specifically, the article discusses the disclosures and manifestations of solidarity covered by the Franco-German press during the economic crisis. The study is carried out via content analysis and discourse theory.
\end{abstract}

Keywords: solidarity, eurozone crisis, European mentalities, media manifestations and discourse

\section{Introduction}

Since the start of the eurozone sovereign debt crisis, the term "solidarity" has come to the forefront of the European Union (EU) political agenda. In particular, the debate on European solidarity saw a significant boost from 2008 onwards, when more and more European countries were hit by the global economic crisis. A small group of EU countries (Portugal, Ireland, Greece, and Spain) questioned the existence of the eurozone because of their poor economic performance and their inability to face the new financial and economic situation. The European economic crisis raised many questions about the future of the eurozone; however, more concerns about democracy, solidarity, and unity in the EU were raised.

Solidarity is an ambiguous term. It may be used as a ploy in political rhetoric to hide that the phenomenon of solidarity is missing or to denote that there is a feeling of togetherness, a sense of loyalty, trust, and fairness. Solidarity, one of the core EU values, has a long history in Europe, and has been included as a guiding principle in many European policies (e.g., financial policy, energy policy, asylum policy). The media, by bringing related issues to the attention of the public and the political elites, can raise awareness and can contribute to the development of a European solidarity discourse.

The aim of this paper is to examine the role of the European media in the coverage of the EU crisis under the spectrum of solidarity. The question posed by Habermas of "solidarity among strangers" is more applicable than ever in the European context alongside the role of the media as a solidarity-building consciousness. Two member states, Germany and France, have played a pivotal role in the process of integrating Europe and seem to take the reins regarding the future of Europe. Thus, we focus on the Franco-German press, and we explore whether the media's coverage deals with issues of solidarity and what type of discourse the media engender about Europe.

The paper unfolds as follows: In section 1, we provide a discussion on solidarity by investigating its theoretical background and emphasizing the most important aspects. In section 2, we draw upon the findings of section 1 and explore the concept and issues of solidarity within the European context. Having established the theoretical framework, the social and economic-political discourse governing EU politics on solidarity, we begin the empirical part of the article. Here, we explore the what, the how, and the why of the media coverage concerning European solidarity. In the last section, we summarize and conclude. 


\section{Conceptualizing Solidarity: Basic Concepts and Definitions}

Solidarity is often used in a vague and undetermined sense, somehow hidden within the political rhetoric of actors, political parties, and/or institutions such as EU members and institutions. Therefore, the term solidarity requires clarification and historical contextualization within the particular political spectrum under investigation (Liedman, 2002; Wilde, 2007).

Methodologically speaking, the notion of solidarity could be addressed in the following way: According to Quentin Skinner (1980), studying an idea involves examining three things. First, the society within which this idea is formulated. Second, the term itself, which refers to the use of the different equivalents of the same word (e.g. brotherhood, fraternity, unity). The third is the context, which can be divided into the conceptual context, the political context, and the historical or structural context. The conceptual context refers to the relationship between the concept in question and other concepts, the political context refers to the relationship between political parties and alternative strategies whereas the historical/structural context refers to the economic boundaries nationally or internationally (Stjernø, 2005).

At the heart of solidarity lies the important sociological issue of inclusion versus exclusion. This is one reason solidarity figured so prominently in the work of the classical sociological theory of Emile Durkheim and Georg Simmel; both considered solidarity the constitutive element that made society possible (Durkheim, 1893; Simmel, 1908; Wilde, 2007). Although Durkheim distinguished between mechanical and organic solidarity, Simmel noted the role of religion as the common factor in all social order. Similarly, political philosophers such as Jürgen Habermas (1995) in his communicative theory and Luhmann (1995) in system theory considered the significance of solidarity in political discourse. The Marxist tradition beginning with Marx himself understood solidarity in the form of class solidarity, which was later developed differently by Kautsky (1915), Gramsci (1971), and Lenin (1967). Structurally and ideologically, the use of solidarity within the Marxist arena was discussed exclusively as the solidarity of the working class.

However, the exploration of the use of solidarity within the recent European political spectrum is crucial. Solidarity as a concept has historically changed (Note 1) and focused on broadening democratic participation. The Social Democrat solidarity concept poses the issue of individualism versus collective action (Freeden, 1996, p.443). Since the late 1980s, many Social Democrat political programs tried to reconcile the freedom of the individual to pursue his or her interests and the needs of the community. The Christian Democrat agenda emphasizes subsidiarity and personal responsibility and confers a weaker role upon solidarity (Stjernø, 2005, pp. 240-242). However, there is a sector within Christian Democrat discourse that pays particular attention to solidarity issues (i.e. Social Christians). In other words, both parts of the European discourse on solidarity face the issue of individualism versus collective action but from different perspectives.

Generally speaking, the issue of individualism is raised due to the increased level of social mobility, the change in education to more individualist patterns and the acute concerns with the specialization of science, which consequently has led to increased specialization in the work arena as well. Moreover, the recent financial crisis in the eurozone, especially in the Mediterranean countries, produced a certain degree of distrust regarding the welfare state itself as well as a common ground for solidarity.

\section{Expressions of Solidarity: Looking into the Concept of European Solidarity}

In the last section, solidarity and its many manifestations were investigated. However, the question remains. What does solidarity mean in the European context? Does solidarity encompass self-interest, community, altruism, and political obligation? How are these concepts envisaged, exercised, and interrelated within the European structure and policy? Do democracy and sovereignty underpin the dynamics that shape solidarity in Europe? Is European solidarity a matter of value (the moral imperative to help someone in need, to help one of us)? Is it mutual in terms that refer to fair sharing of responsibility and coordination between member states in certain domains? And, if so, is inter-state solidarity rooted in individualism or collectivity? In the following sections, we try to shed some light on these questions.

\subsection{The Different Rationales for Inter-State Solidarity in the EU}

"Europe will not be made all at once, or according to a single plan. It will be built through concrete achievements which first create a de facto solidarity." (Robert Schuman, The Schuman Declaration, May 9, 1950)

Although solidarity was one of the constitutional principles of the European construction, it is not clear how the notion of European solidarity is defined, what are the legal, political, economic, and moral limits of European 
solidarity, what solidarity means in the framework of the EU, and in particular in the context of the Economic and Monetary Union (EMU), and what kind of and how much solidarity have been exercised thus far.

A discussion of solidarity and the EU is related to Durkheim's thinking on solidarity and the process of differentiation in which ties of organic solidarity across national borders intensify, and ties of mechanic solidarity within national boarders weaken. In Emile Durkheim's classic work The Division of Labor in Society (1893), "mechanical solidarity" characterizes primitive societies. The members of that society are more likely to resemble each other and share the same beliefs and morals. Solidarity is emotional and grounded on a shared identity and the moral imperative of helping one of us. As societies become more advanced and civilized, the individual members of those societies start becoming more unique and distinguishable from each other. Solidarity becomes more organic as these societies develop their divisions of labor. In particular, "organic solidarity" is understood as a natural outcome resulting from social interactions generated by the division of labor in modern societies and is based on a system of different functions united by definite relationships. Social cohesion, then, is the result of these interactions and relationships that create interdependence among individuals. Because they are interdependent, society's members have to rely on each other and to commit to mutual assistance, if their society is to function effectively. Sofia Fernandes and Eulalia Rubio (2012) in their study (Note 2) for the think tank Notre Europe argue that European solidarity in the EU is organic solidarity, that is, functional than emotional:

While EU countries hold some common values, it is the awareness of being ultimately connected and mutual responsible for the preservation of a common project that has prompted the development of inter-state solidarity arrangements all over the history of the European integration (Fernandes \& Rubio 2012, p. 4).

More specifically, they maintain that a distinction can be made between two different rationales inspiring inter-state solidarity in the EU, namely, direct reciprocity (I help others so that they will help me in the future in case of need) and enlightened self-interest (I help others because I know that acting in the interest of other EU members or in the interest of the EU as a whole ultimately serves my own self-interest) (Ibid).

Many EU solidarity efforts have been driven by the logic of enlightened self-interest as it is reflected in EU cohesion policy. The strong EMU countries help the weaker or poorer EMU countries in order to guarantee the cohesion and stability of the European Union and to ensure the countries are economically integrated (Fernandes \& Rubio, 2012, p. 7). In this case, solidarity is driven by the donor EU countries' conviction that helping the recipient countries ultimate benefits them (Note 3 ).

The direct reciprocity solidarity logic in the EU underpins the classic insurance-type schemes: for example, the EU Solidarity Fund, which comes to the aid of any member state affected by a natural disaster, or the Lisbon Treaty's "solidarity clause" according to which member states "shall act jointly in a spirit of solidarity if a member state is the object of a terrorist attack or the victim of a natural or man-made disaster", [article 222 of the Treaty on the Functioning of the European Union - TFEU] (Note 4), (Fernandes \& Rubio, 2012, pp. 4-5). The ultimate purpose of this solidarity arrangement is to provide reciprocal aid in face of a risk that is evenly spread across all the EU member states. All EU countries then are potential givers and receivers of help and today's provider of help can be tomorrow's beneficiary (Fernandes \& Rubio, 2012, p. 5).

However, solidarity is not a one-way approach but has to include commitments of responsibility. As noted by Jérôme Vignon (2011), any solidarity act has a counter-part element of responsibility from the country receiving the aid, and solidarity only grows stronger with consequent responsibility. Moreover, the exercise of inter-state solidarity in the EU concerns coordination. Coordination can serve to diagnose, prevent and redress divergences within a group and can help reduce risks such as the current debt crisis.

\subsection{Solidarity within the EMU: An "Imagined Community"?}

The creation of the EMU was enshrined with the signature of the Treaty of Maastricht (Treaty on European Union or TEU) in 1992. Apart from setting the calendar for the launch of the Euro, the Treaty endorsed the principle of solidarity (Note 5) in the European Union's policy fields (e.g., external action on the international scene [Art $21 \mathrm{TEU}$ ], common foreign and security policy [Art 24.2, $31 \mathrm{TEU}$ ]) and introduced provisions related to solidarity and coordination within the EMU (Note 6). These provisions reflected considerations about the impact of the EMU on the weaker economies and on national governments' capacity to stabilize their economies. In particular, the treaty enshrined cohesion as an essential objective of the European Union, in parallel with economic and monetary union and the single market. The treaty created new cohesion instrument, that is, The Cohesion Fund, which was designed to help the poorest countries due to join the EMU (Greece, Portugal, Ireland, and Spain), an effort that was boosted by the Second Delors Package. 
However, solidarity and coordination were debated in two contrasting visions: Germany and France. The French position was reflected in Art 103 TEU, which stated that member states should regard their economic policies "as a matter of common concern," whereas the German position was mainly reflected on the introduction of a "no bail-out" clause (Art 104b TEU), which actually forbids the European Union from helping an EMU country that fails to meet its financial obligations. The latter seems to contradict to some extent, the vision of Europe envisaged in the TEU and the Lisbon Treaty, where the European Union "shall promote economic, social and territorial cohesion, and solidarity among Member States."

In January 1999, the euro was introduced. During the first decade the euro existed (1999-2009), the EMU functioned relatively well in terms of the international presence of the euro, low inflation interest rates and job creation (Note 7). The eurozone crisis in 2010 forced member states to adopt rigorous austerity measures to reduce public deficits and public debt. In particular, the southern countries in the eurozone were trapped in the recession and become uncompetitive. Obviously, important measures have been taken (e.g., rescue packages to Greece [May 2010], Ireland [December 2010], Portugal [May 2011]), by the EU to help member states in need. However, the strict conditions attached to the aid packages as well as the delay in helping these countries leads to questions about the altruistic motivations behind them and raise concerns if these measures are indeed proof of EU solidarity. As Fernandes and Rubio (2012, p. 20) argue, the exercise of solidarity during the crisis was obstructed by the EU leaders' difficulty identifying their interest in helping the others, as well as by the actual lack of solidarity mechanisms in place, ready to be activated in order to provide financial support to an EMU country in need (Note 8). Eventually, solidarity, responsibility, self-interest and provision are interconnected.

Beyond the continuing crisis and any political manifestations of solidarity, there are some signs which indicate that Europeans remain committed to working together to get out of the crisis and to give financial support to member states facing severe economic problems. For example, in autumn 2012, the majority of Europeans said that EU countries would have to work more closely together (84 percent), (Standard Eurobarometer, 2013) (Note 9).

\section{Revealing Solidarity? The Coverage of European News by the Media: The Case of the Franco-German Press}

As we saw in the last sections, solidarity has been recognized as the guiding principle of many EU policies (e.g., financial [Art $141 \mathrm{TEU}$ ], external action on the international scene [Art $21 \mathrm{TEU}$ ], common foreign and security policy [Art 24.2, 31 TEU]), particularly, in security policy [Art 222 1(a), (b) TFEU]. Moreover, the principle of solidarity has been elaborated in asylum and immigration policy and more specifically in Article 80 of the TFEU, which provides that EU policies on border checks, asylum, and immigration must be governed by the principle of solidarity and fair sharing of responsibility, including its financial implications, between the Member States'. In the same vein, Article 194 TFEU stipulates that the European Union's energy policy should be exerted in a spirit of solidarity between member states in order to: (a) ensure the functioning of the energy market, (b) ensure the security of the energy supply in the European Union, (c) promote energy efficiency and energy saving and the development of new and renewable forms of energy, and (d) promote the interconnection of energy networks.

Taking into account the findings discussed in the previous sections, in this part of the article we examine how European solidarity is communicated by the media to the European public and how solidarity is portrayed by the European press.

\subsection{Methodological Considerations}

The European crisis has received significant coverage by the media (Note 10). However, the power of the media to construct a reality about Europe lies not only in extensive coverage. It is also a matter of selection and mediation of the news. The media are key players in promoting a European public sphere of mutual understanding based on solidarity and community interest. Equally, by restoring stereotypes and being biased, they can generate a lack of understanding as well as delimit a sense of belonging and unity. Solidarity is one of the constitutional principles of the European construction and the main theme in the European agenda, which sprang up mainly during the eurozone crisis. As researchers have noted, media coverage of crises often produces solidarity (Note 11). Whether a crisis generates solidarity largely depends on how the news media cover the event, what kind of information is made available to the public, and how they portray basic actors. The media create a certain reality about things, entities and communities, produce meanings, reflect social constructions and consequently set a conceptual framework or a "symbolic environment" through which the public draws pictures and beliefs about various issues (Note 12). 
In this section, we examine the what, the how, and the why of the media coverage of European solidarity. We focus on France and Germany, the largest of the eurozone economies, and which have been crucial actors in shaping the European Union since its inception. In addition to political and economic weight, France and Germany have played an important role in the decision-making processes concerning Europe's fiscal and monetary developments as well as in decisions regarding the European sovereign debt crisis.

We chose four opinion-forming newspapers, two from France and two from Germany, (Note 13) which represent the mainstream public discourse and political spectrum and provide daily and national coverage (Note 14). These newspapers are the German Frankfurter Allgmeine Zeitung (FAZ) (conservative/liberal) and Süddeutsche Zeitung (SZ) (liberal/left wing) and the French Le Monde (center/left wing) and Le Figaro (conservative/right wing).

The electronic archives of these newspapers (Note 15) as well as a number of their print material were reviewed systematically for one vear, from January 1. 2013, to December 31. 2013. We focus on 2013 because we want to examine the most recent developments regarding the question under examination. Additionally, by concentrating on one year of media coverage we provide a consistent review of the media's treatment of the subiect. The search is refined according to the kevword Europe - solidaritv translated into French (Europe solidarité) and German (Europa Solidarität). The research generated a number of articles, which were reviewed (headlines associated with a specific summary content) and filtered according to their relevance to the subiect matter (Note 16). For analyzing the data, quantitative and qualitative methods were used. In particular, we used content analysis (quantitative content analysis) (Note 17) supplemented by discourse analysis (Note 18).

In the present study, content analysis is concerned with "what is said in the text?" (i.e., the themes) and "how often is it said?" (i.e.. the frequency), and thus gives the main picture, uncovers fundamental trends of coverage. and establishes an essential framework for further research. Discourse analysis enhances the text with the qualitative perspective of the concept of solidarity within the European agenda. In particular, it highlights the moments of disruption of the hegemonic nodal point (European solidarity) when the opinions expressed in the Franco-German press are analyzed.

\subsection{Exploring the Coverage: The What, the How, and the Why of Media Coverage on Solidarity}

How did the media deal with the issue of solidarity? How visible was the issue of European solidarity in the European press? What were the most prominent themes in the press coverage? Which aspects of solidarity prevailed the most? Which discourse emerged from the media coverage?

In this section, we provide an analysis of the quantity and range of European information regarding various aspects and dimensions of European solidarity. Then we discuss the discourse of the media coverage.

Table 1. Frequency of stories referring to aspects of European solidarity: January-December 2013

\begin{tabular}{|c|c|c|c|c|}
\hline & \multicolumn{2}{|c|}{ French Newspapers } & \multicolumn{2}{|c|}{ German Newspapers } \\
\hline & Le Figaro & Le Monde & FAZ & $S Z$ \\
\hline Num. & 72 & 75 & 54 & 67 \\
\hline Total & \multicolumn{2}{|c|}{147} & \multicolumn{2}{|c|}{121} \\
\hline
\end{tabular}

Table 1 provides information about the frequency of stories on European solidarity in the French and German press. As is evident in Table 1, news that refers to Europe and discusses aspects of solidarity or indicates its absence is quite visible in the French and German press coverage. The French press takes the lead in reporting by providing as much as 55 percent of the overall coverage, whereas the German press follows with 45 percent. The higher interest by Le Monde and Le Figaro compared to FAZ and $S Z$ can be attributed to the different perceptions that France and Germany may have regarding the meaning of the principle of solidarity and the endorsement of it within the European context. Moreover, the difference could also reflect variances in each medium's coverage and style as well as different media traditions.

During the period assessed, reporting on European issues dealing directly or indirectly with solidarity issues or mentioning solidarity was a recurring theme in media coverage. That is not surprising, since the continuing European crisis, apart from the question of democracy and legitimacy in the EU, has also put on the agenda the question of solidarity. Moreover, during the period under examination, significant events such as the migrant shipwreck tragedy in Lampedusa, the Cyprus bankruptcy, the anniversary of the Elysée Treaty, and the war in Mali attracted the media's attention. Eventually, due to their content these incidents raised issues of solidarity. 
Additionally, in many cases the same articles related to these events were circulated for more than a day, which thus increased the numbers in the coverage. These events combined with more continual themes and actors in the EU media coverage (e.g., stability packs and mechanisms, states' deficits and austerity measures, unemployment) provide the length and breadth of the media coverage.

The types of European news that deal with aspects of European solidarity can be categorized into two broad primary groupings: (a) news that deals with EU affairs and covers aspects of economic and political solidarity and (b) news that tackles various aspects of social solidarity in Europe.

Into the first category would fall stories related, for example, to EU summits and European councils, Euro group meetings, European institutions, national actors such as Chancellor Angela Merkel or State actors such as France, EU statements, and decisions and procedures related to financial and political issues. The principle of European solidarity in financial and political terms is often circumvented by states' deficits, solidarity financial mechanisms, the role of the Franco-German axis in decision making, EU inter alia relations, discussions of the EU's security policy and foreign affairs, and EU energy policy (Note 19).

The second category would include stories concerning solidarity in social terms. The principle of social solidarity can be articulated through news stories that deal mainly with political and economic decisions and policy measures referring to immigration and asylum issues, illegal migration, trafficking, intra-EU mobility of workers, unemployment, human and trade rights, European society and European citizens, the everyday life of Europeans, and statements regarding the EU values (Note 20).

The first elaboration of the reviewed articles indicates that news referring to the first category is more frequent in the agendas of the newspapers we examined. This is quite expected, because the first category is broad and because as research has shown (e.g., Semetko, De Vreese, \& Peter, 2000; De Vreese, Peter, \& Semetko, 2001), political and economic news regarding Europe is the prevailing feature of media coverage. Moreover, the EU project itself has been mainly centered on economic and political decisions, and the EU crisis was primarily a debt financial crisis. Approximately 78 percent of the coverage focused on stories that discuss the presence or absence of financial and political solidarity, whereas 22 percent falls toward the coverage of social aspects of solidarity. The differences between the French and German press are minor, with the German press providing on balance slightly more articles (about five) on social solidarity, particularly due to the focus on the tragedy at Lampedusa and consequently on asylum and EU immigration policy. The tragedy at Lampedusa has caused many concerns in the EU about responsibility, cooperation, and solidarity among the EU member states. Germany has received pressing calls from EU officials to accept larger numbers of asylum seekers in order to reduce the burden on Italy and other countries such as Greece, within striking distance for leaky boats from Africa and Asia as well as to reconsider the EU asylum and immigration policy.

Many articles that represent the basic themes and cover the most significant aspects of European solidarity are analyzed in the following section to reveal the discourse that emerged in the Franco-German press and shed light on the points of disruption.

\subsection{Discursive Constructions on Solidarity}

Drawing on a hermeneutic perspective, discourse theory seeks to uncover power relations within deeply embedded social constructions and underlying logics of political action. The key methodological tool for such an analysis is hegemony, as has been elaborated by Laclau and Mouffe (1985). This elaboration went through three models: The first model challenges the orthodox Marxist notion of a "necessary class belonging" transcending all the ideological elements of society. Therefore, for Laclau (1977) and Mouffe (1979) the identities of all social agents are contingent. The second model introduces nodal points, fixed hegemonic formations underpinning the social order (Laclau \& Mouffe, 1985, p. 142). Finally, at the heart of the third model lies dislocation, which refers to unsymbolized events, external to the hegemonic order and aiming at its disruption (Laclau, 1990).

Schuman's (1950) declaration that "Europe as a de facto solidarity project," thus posing solidarity among the main constitutional principles, suggests that solidarity constitutes a fixed hegemonic formation, therefore a nodal point (Laclau \& Mouffe, 1985, p. 142). The crucial point within this discussion is to shed light on the dislocatory practices, which aim at disrupting solidarity. These practices can intersect the principle of direct reciprocity and the enlightened self-interest, since they tend to be within self-interest rather than collective action.

The major issue (Note 21) behind the agenda of European solidarity is the economic self-interest of the members of the Eurozone, and mainly the leading ones. In this perspective, European solidarity is equivalent to the monetary union, and without this, its existence is at risk. According to Le Monde, "with budgetary harmonization, European solidarity funds, and perhaps the soon-to-be-implemented coordination of economic policies, the 
banking union will give the monetary union a material existence which has long been overdue" (Note 22). Balanced budgetary policies are linked to numerous issues in terms of financial and social solidarity.

The first issue is unemployment, which recently has hit the eurozone, especially countries affected by the 2008 economic crisis. As stated in Le Monde, "it is time to devise a budget that prepares the future and shows true, federal solidarity for the regions hardest hit by massive unemployment" (Note 23). In the same line of thought, François Hollande observed the high unemployment figures for 2013 and proposed a "pact of responsibility" with "less stress" for companies to "win" the "battle" of employment (Note 24).Therefore, it is necessary to take structural measures within the margins of the eurozone. The second issue is the role of the European Credit Bank (ECB), whether it should be a direct monitoring unit or a banking supervision body. In the case of the ECB as a monitoring unit, agreements (Note 25) such as the one reached on March 16, 2013, between Cyprus, the Eurogroup, and the International Monetary Fund (IMF) would endanger the relationship among the eurozone countries. Such measures can be called arbitrary and hazardous for European solidarity and the free movement of capital within the EU and signify dislocatory practices. Therefore, in cases of an unbalanced budget or an extreme deficit, the issue of solidarity is disrupted, and the self-interest of powerful economies prevails over that of countries experiencing economic crises, such as Greece, Ireland, or Spain.

From another point of view, the issue of the disruption of European solidarity can be seen in cases of defense policy, where a common defense program is not implemented and each country has to act according to its self-interest rather than collective action. That's why the commentator in Le Monde (Note 26) speaks about "Stinginess and stupidity," when he refers to the French initiative to send troops in Mali. In his own words: "For sure, Paris was wrong at the start to send in its troops without consulting with its partners. But a true European solidarity would have been necessary then, a show of common interest, a common defense - in short, the sharing of a burden that will have to be carried in the future."

Finally, an important issue as a moment of disruption within the hegemonic project of solidarity is the immigration policy transgressing the eurozone following the Dublin Convention (1990, amended as the Dublin Regulation in 2003 and 2013). According to the regulation, refugees can request asylum only in the first country they reach. If they decide to request asylum from another state, the latter may decide to examine the application on humanitarian grounds. The regulation has been criticized, and the M.S.S. (Note 27) judgment of the European Court of Human Rights and the N.S. (Note 28) judgment of the Court of Justice of the European Union revealed serious deficiencies in the system (Note 29). Both judgments emphasized that "asylum seekers must not be transferred to a Member State whose asylum system manifests systematic deficiencies." (Note 30). Reforming this regulation would mean refugees could request asylum in other European countries apart from the first one the refugee has entered. As stated in De Morgen, "Southern-European countries certainly need to be reminded of their responsibility to offer migrants and refugees a decent reception. For Northern European governments, however, the simple willingness to receive refugees will be a plausible gesture of solidarity too." (Note 31). Thus, as an overall perspective, if European governments wish to accept their responsibility (Note 32) on the issue of immigration, they could reform the particular regulation and openly show their solidarity with southern European countries, which receive numerous asylum seekers daily. The EU commissioner for home affairs, Cecilia Malmström, has spoken repeatedly of the joint responsibility of European countries together with a sense of solidarity and even a "genuine common European asylum policy" (Note 33). Similarly, as stated in Die Presse, (Note 34) Malta's prime minister has explained:

'that Southern Europe deserves greater solidarity and the other countries must also absorb the new arrivals. If Germany were to take charge of a number of migrants proportional to the number taken on by Malta, nearly a million people would be concerned. This incident shows that in 2013 the EU has not found a solution to the distribution of the "boat people".'

That's why the European Parliament president, Martin Schulz, observed, "Germany must accept additional people" (Note 35). One of the poorest member states of the European Union, Bulgaria, has welcomed nearly 10,000 illegal immigrants since the beginning of 2013, 60 percent of them Syrians (Note 36). As a result, on September 16, 2013, "the Bulgarian government appealed for 'European Solidarity', and called on other EU member states to take charge of the asylum seekers" (Note 37).

\section{Conclusions}

The EMU crisis has brought to light major EU construction problems, which reflect significant economic and social issues. Successful projects such as the creation of the single market and the introduction of a common currency have been overshadowed by the shortcomings of macroeconomic coordination, as well as the comparably slow development of the EU's social dimension (Bischoff \& Kallweit, 2011, p. 3). Democracy, 
sovereignty, unity, and eventually solidarity have been at the epicenter of the European discussion. The question of whether solidarity has remained a common principle for the EU has arisen many times, denoting not only a lack of democracy but also a European public profoundly disconcerted and disappointed by European politics and distant from the common European dream.

If, as Durkheim and Simmel have stated, society is not possible without solidarity, then it is hard to imagine the current European society and the European Union's future without solidarity. It is also hard to imagine an informed, active, and responsible European public, without taking into account the role of the media. Indeed, the media play an important role, since they inform the European public for the EU, mediate European values, transcend European attitudes, form mentalities, and create an "imagined community" for Europeans.

The findings of our research indicate that the European press focused on covering issues (of economic, social, political nature) related to solidarity, thus bringing directly or indirectly, loudly or quietly significant matters into the attention of the public. The coverage of the themes was mainly event-driven. However, reporting reflected a shift in the European agenda and in the EU elite political rhetoric, where solidarity circulated considerably, mainly as a result of constant calls to show solidarity in the nations that suffered during the eurozone crisis and as a solution to preserve legitimacy and democracy in the EU. Likely, the role of the media as a watchdog started to gain ground. The resulting common coverage (with not really significant differences in terms of frequency and types of themes) by the media under investigation suggests that the press functioned to some extent as a homogenous entity. Similarly, the media did not contribute to substantial divergent narratives of the Euro crisis and solidarity and instead conveyed the same discourse.

In particular, many issues raised by the media denote the lack of solidarity within the European agenda concerning financial bankruptcy, foreign policy and immigration. The responsibility lies at the heart of the eurozone countries, especially the member states that participate in the European decision-making agenda. The issue is whether this responsibility is accompanied by trust and respect for the member states that implement austerity measures due to the economic crisis, the lack of a common EU foreign policy, and the huge wave of illegal immigrants. Responsibility and trust do not seem to go hand-in-hand but undergo numerous adversity with significant consequences for the European mentality. In other words, living in a Europe where democracy has been questioned, blackmail tends to but should not replace solidarity as a mentality.

Finally, solidarity should be a principle and an outcome in every political debate among unequal partners. Beyond, any rhetoric solidarity should represent a mutual commitment to jointly cultivate a European model founded on loyal cooperation, democracy, liberty, and respect, a model based on "unity in diversity".

\section{References}

Bandura, A. (1977). Social Learning Theory. Englewood Cliffs, N.J.: Prentice-Hall.

Becker, L. B. (1982). The Mass Media and Citizen Assessment of Issue Importance: A Reflection on Agenda-Setting Research. In D. C. Whitney, E. Wartella, \& S. Windahl (Eds.), Mass Communication Review Yearbook (Vol. 3, pp. 521-536). Beverly Hills: Sage.

Berelson, B. (1952). Content Analysis in Communication Research. New York: The Free Press.

Bischoff, G., \& Kallweit, A. (2011). Introduction. Solidarity in the Economic Crisis: Challenges and Expectations for European Trends Unions. International Policy Analysis, Friedriech Ebert Stiftung (pp. 3-18). Retrieved November 9, 2013, from http://library.fes.de/pdf-files/id/ipa/08073.pdf

Clayton, G. (2011). Asylum Seekers in Europe: M.S.S. v Belgium and Greece. Human Rights Law Review, 11(4), 758-773. Retrieved March 12, 2014, from http://www.corteidh.or.cr/tablas/r27639.pdf

Council of Europe: European Court of Human Rights, M.S.S. v. Belgium and Greece. Application No. $30696 / 09$. 21 January 2011. Retrieved March 12, 2014, from http://www.refworld.org/docid/4d39bc7f2.html

Court of Justice of the European Union. An Asylum Seeker may not be Transferred to a Member State Where he Risks being Subjected to Inhuman Treatment. Press release No. 140/11. Luxembourg, 21 December 2011. Retrieved March 12, 2014, from http://curia.europa.eu/jcms/upload/docs/application/pdf/2011-12 /cp110140en.pdf

De Vreese, C. H., Peter, J., \& Semetko, H. A. (2001). Framing Politics at the Launch of the Euro: A Cross-National Comparative Study of Frames in the News. Political Communication, 18(2), 107-122.

Durkheim, E. (1893). The Division of Labour in Society. London: Macmillan. 
European Commission - Eurobarometer. (2013). Public Opinion in the European Union. Standard Eurobarometer 79 (Spring). Retrieved November 9, 2013, from http://ec.europa.eu/public_opinion/archives /eb/eb79/eb79_first_en.pdf

Fernandes, S., \& Rubio E. (2012). Solidarity within the Eurozone: How Much, What For, For How Long? Report, No. 51, Notre Europe. Retrieved November 9, 2013, from http://www.notre-europe.eu/uploads /tx_publication/SolidarityEMU_S.Fernandes-E.Rubio_NE_Feb2012.pdf

Freeden M. (1996). Ideologies and Political Theory. A Conceptual Approach. Oxford: University Press.

Gerbner G., Holsti O. R., Krippendorff K., Paisley W. J., \& Stone, P. J. (Eds.). (1969). The Analysis of Communication Contents: Developments in Scientific Theories and Computer Techniques. New York: Wiley.

Gerbner, G. (1973). Cultural Indicators -The Third Voice. In G. Gerbner, L. Gross, \& W. Melody (Eds.), Communication Technology and Social Policy (pp. 553-573). New York: Wiley.

Glynos, J., \& Howarth, D. (2007). Logics of Critical Explanation in Social and Political Theory. Abingdon: Routledge.

Goldner, L. I. (2013). Is There Solidarity on Asylum and Migration in the EU? Croatian Yearbook of European Law and Policy (Vol. 9, No. 9). Retrieved January 8, 2014, from http://www.cyelp.com/index.php/cyelp $/$ article/view/172

Gramsci, A. (1971). In Q. Hoare, \& G. N. Smith (Eds.), Selections from the Prison Notebooks. New York: International Publishers.

Habermas, J. (1995). Reconciliation Through the Public Use of Reason: Remarks on John Rawls's Political Liberalism. Journal of Philosophy, 92(3), 109-131. http://dx.doi.org/10.2307/2940842

Hawdon. J., Oksanen. A., Räsänen, P., \& Ryan, J. (2012). School Shootings and Local Communities: An International Comparison between the United States and Finland. Turku: University of Turku Press.

Holsti, O. (1969). Content Analysis for the Social Sciences and Humanities. London: Addison Wesley.

Howarth, D. (2000). Discourse. Buckingham: Open University Press.

Kautsky, K. (1909). The Road to Power (Trans. A. M. Simons). Chicago: Samuel A. Bloch.

Krippendorff, K. (1980). Content Analysis: An Introduction to Its Methodology. London: Sage.

Laclau, E., \& Mouffe, C. (1985). Hegemony and Socialist Strategy: Towards a Radical Democratic Politics. London: Verso.

Laclau, E. (1977). Politics and Ideology in Marxist Theory. London: Verso.

Laclau, E. (1990). New Reflections on the Revolution of Our Time. London: Verso.

Lenin, V. (1902). What is to be Done? Moscow: Progress Publishers.

Liedman, S. (2002). Solidarity. Retrieved May 20, 2014, from http://www.eurozine.com/authors/liedman.html

Luhmann, N. 1995 (1984). Social Systems. Stanford: Stanford University Press.

Malcolm, R. M. (2010). Solidarity: A New Constitutional Paradigm for the EU? In M. Ross \& Y. Borgmann-Prebil (Eds.), Promoting Solidarity in the European Union (pp. 23-45). Oxford: Oxford University Press.

McCombs, M. E., \& Shaw, D. L. (1972). The Agenda-Setting Function of the Press. Public Opinion Quarterly (Vol. 36, pp. 176-187). http://dx.doi.org/10.1086/267990

McQuail, D. (1977). Analysis of Newspapers Content. Royal Commission on the Press Research Series 4. London: HMSO.

Merten, K. (1996). Reactivity in Content Analysis. Communications, 21(1), 65-76. http://dx.doi.org/10.1515 /comm.1996.21.1.65

Mouffe, C. (Ed.) (1979). Gramsci and Marxist Theory. London: Routledge \& Kegan Paul.

Mylonas, Y. (2012). Media and the Economic Crisis of the EU: The 'Culturalization' of a Systemic Crisis and Bild-Zeitung's Framing of Greece. Journal for a Global Sustainable Information Society, 10(2), 646-671. Retrieved November 9, 2013, from http://www.triple-c.at/index.php/tripleC/article/view/380 
Open Society Foundations. (2013). Solidarity in Europe. Retrieved November 9, 2013, from http:/www.opensocietyfoundations.org/press-releases/europe-stands-firm-europeans-back-solidarity-over-n ational-self-interest-get-out

Quiring, O., \& Weber, M. (2012). Between Usefulness and Legitimacy: Media Coverage of Governmental Intervention during the Financial Crisis and Selected Effects. The International Journal of Press/Politics, 17, 294-315. http://dx.doi.org/10.1177/1940161212442957

Rogers, E. M., \& Shoemaker, F. (1973). Communication of Innovations. Glencoe: Free Press.

Schuman, R. (1950). The Schuman Declaration. European Union. Retrieved March 12, 2014, from http:/europa.eu/about-eu/basic-information/symbols/europe-day/schuman-declaration/

Semetko, H. A., De Vreese, C. H., \& Peter, J. (2000). Europeanised Politics - Europeanised Media? European Integration and Political Communication. West European Politics, 23(4), 121-141. http://dx.doi.org/10.1080 /01402380008425403

Shapiro, M. A., \& Lang, A. (1991). Making Television Reality: Unconscious Processes in the Construction of Social Reality. Communication Research, 18(5), 685-705. http://dx.doi.org/10.1177/009365091018005007

Shoemaker, P. J., \& Reese, S. D. (1996). Mediating the Message. White Plains, N.Y.: Longman.

Simmel, G. (1908). Sociology: Investigations on the Forms of Sociation. Leipzig: Duncker \& Humblot.

Skinner, A. (1980). The Foundations of Modern Political Thought (Vols. I-III). Cambridge: Cambridge University Press.

Stjernø, S. (2005). Solidarity in Europe: The History of an Idea. Cambridge: Cambridge University Press. http://dx.doi.org/10.1017/CBO9780511490378

Treaty on European Union and the Treaty establishing the European Economic Community. Consolidated versions [2006] OJ C321 E/1.

Treaty on Lisbon amending the Treaty on European Union and the Treaty establishing the European Community [2007] OJ C306/01.

Treaty on the Functioning of the European Union. Consolidated version [2008] OJ C115/47.

Tzogopoulos, G. (2013). The Greek Crisis in the Media: Stereotyping in the International Press. Surrey: Ashgate.

Vignon, J. (2011). Solidarity and Responsibility in the European Union. Notre Europe Policy Brief, No. 26, June 2011. Retrieved November 9, 2013, from http://www.notre-europe.eu/uploads/tx_publication/Bref27 JVignon_EN.pdf

Wilde, L. (2007). The Concept of Solidarity: Emerging from the Theoretical Shadows? British Journal of Politics and International Relations, 9(1), 171-181. http://dx.doi.org/10.1111/j.1467-856X.2007.00275.x

\section{Notes}

Note 1. Stjernø (2005, pp. 93-96) suggests three possible explanations for the historical change in the use of solidarity. First, it is a change in the class structure and the need for electoral alliances. If solidarity had remained solely the closed space of the working classes, smallholders and the new middle class would not have been able to participate within new electoral alliances. Second is the cultural change after 1968 that rendered the need for social democracy to broaden the concept of solidarity acute, and third is the nature of political symbols and programs.

Note 2. Fernandes, S. \& Rubio, E. (2012). Solidarity Within the Eurozone: How Much, What For, For How Long?, Report, No. 51, Notre Europe.

Note 3. Wealthier countries help poorer EU countries to develop their economies in exchange for their engagement to the process of economic integration. In the short term, this provides more benefits for richer countries than for poorer economies. Wealthier countries realize that developing poorer economies has positive economic returns for them in terms of increasing exports, increasing investment opportunities, or decreasing population inflows among others (Fernandes \& Rubio, 2012, p.5).

Note 4. "The Union shall mobilize all the instruments at its disposal, including the military resources made available by the Member States, in order to: prevent the terrorist threat in the territory of the Member States; to 
protect democratic institutions and the civilian population from any terrorist attack; assist a Member State in its territory, at the request of its political authorities, in the event of a terrorist attack" [Art 222 1(a) TFEU]; "to assist a Member State in its territory, at the request of its political authorities, in the event of a natural or man-made disaster" [Art 222 1(b) TFEU].

Note 5. Solidarity among the EU member states was acknowledged as one of the main values of the EU: "The Union shall be founded on the European Communities, supplemented by the policies and forms of cooperation established by this Treaty. Its task shall be to organize, in a manner demonstrating consistency and solidarity, relations between the Member States and between their peoples" (Art 2 TEU).

Note 6. For a discussion on the concept of solidarity in different EU law areas, see Malcolm Ross, M. Solidarity: A New Constitutional Paradigm for the EU?. In M. Malcolm Ross \& Y. Borgmann-Prebil (Eds). (2010). Promoting Solidarity in the European Union, (pp. 23-45). Oxford: University Press. See also the above book for an interdisciplinary approach (legal, political, sociological) on the concept of solidarity with reference to the EU.

Note 7. For more on figures, see Eurostat reports.

Note 8. In particular, Fernandes \& Rubio (2012, p.20) take as a starting point the Greek case comment that decisions on whether helping Greece were made by balancing the (high) political cost of breaking the "no bail-out" rule against the benefits of avoiding the unlikely default of a small EMU country representing only 3 percent of the EMU economy. The "Greek problem" started to be seen as an "EMU problem," potentially affecting five EMU economies that sum up almost 40 percent of the eurozone public debt.

Note 9. Moreover, research reveals that people across Europe refuse to blame ordinary people in countries such as Greece for the crisis. Three quarters ( 74 percent) of Europeans surveyed agree that ordinary people in countries like Greece are unfairly suffering the consequences of a crisis that they did not create. Interestingly, an overwhelming 92 percent believe politicians across Europe have lost touch with the suffering of ordinary people in the wake of the financial crisis. Open Society Foundations. Retrieved November 9, 2013, from http:/www.opensocietyfoundations.org/press-releases/europe-stands-firm-europeans-back-solidarity-over-nation al-self-interest-get-out.

Note 10. The role of media in the eurozone crisis has been the subject of research for scholars, see: Tzogopoulos, 2013; Mylonas, 2012; Quiring \& Weber, 2012.

Note 11. For a discussion on the role of media in producing or not solidarity during crises, see: Hawdon et al. 2012.

Note 12. For more on the role of media in constructing reality and the different aspects of this role, see indicatively: McCombs \& Shaw, 1972; Gerbner, 1973; Rogers \& Shoemaker, 1973; Bandura, 1977; Becker, 1982; Shapiro \& Lang, 1991; Shoemaker \& Reese, 1996.

Note 13. For an account on media history and basic features of media landscape in France and Germany, see respectively: http://ejc.net/media_landscapes/france and http://ejc.net/media_landscapes/germany.

Note 14. Circulation: Le Figaro 336,939; Le Monde 340,131; FAZ 382,000; SZ 445,000. Figures available from Presseurop.eu: http://www.presseurop.eu.

Note 15. Accessed via electronic resources like the internet electronic archives of the newspapers under examination (http://www.faz.net, http://www.sueddeutsche.de, http://www.lemonde.fr, http://www.lefigaro.fr/). Additional source, Presseurop.eu: http://www.presseurop.eu.

Note 16. For example, the research on FAZ's online search engine under the headline Europa - Solidarität produced 109 articles; however, only 54 were relevant to our research question.

Note 17. Content analysis is an established systematic technique within the mass communication research and has been widely used by researchers to study how the media treat a range of issues (Berelson, 1952; Gerbner et al., 1969; Holsti, 1969; McQuail, 1977; Krippendorff, 1980; Merten, 1996, etc.). It is a method for the systematic analysis of communication content and involves evaluation and interpretation of texts (Golding, 1990, p.97). Depending on the research goals, content analysis can be used as a quantitative or a qualitative method of research. Content analysis can be used as a tool for characterizing the text, which identifies and counts the occurrence of specified features or dimensions of it and measures what is manifested in the passage (Berelson, 1952). It can also be used as an instrument for recording symbolic reality as well as for unpacking specific values and ideas involved in messages (Merten, 1996). 
Note 18. Discourse theory emerged as a critical theory during the 1980s influenced by the new social movements. It draws upon (among others) the works of Saussure, Foucault, Gramsci, Laclau and Mouffe. Discourse theory has been applied to a number of in-depth political analysis (Glynos \& Howarth, 2007). More precisely, the aim of discourse theory is to evaluate, interpret, and explain the conditions and the meaning of social and political phenomena. In other words, "discourse theory is concerned with understanding and interpreting socially produced meanings, rather than searching for objective causal explanations" (Howarth, 2000, p.128).

Note 19. Examples in this category include articles such as L'Europe de l'énergie, c'est maintenant, Le Monde, 22 May 2013; Feierlichkeiten zum Élysée-Vertrag Merkel und Gauck loben Hollande für Mali-Einsatz, FAZ, 22 January 2013; Mali: la présence militaire française appelée à durer, Le Monde, 22 April 2013; Le nord et le sud de la zone euro divergent encore sur la recapitalisation des banques, Le Monde, 20 January 2013; Appels à une fédération franco-allemande, Le Figaro, 21 May 2013; Union bancaire : un bon accord qui corrige les failles de la zone euro, Le Monde, 12 December 2013; Zypern: Wie Steueroasen mitten in Europa existieren, FAZ, 27 March 2013.

Note 20. Examples in this category include articles such as Katastrophe von Lampedusa: EU uneins über Flüchtlinge, FAZ, 8 October 2013; Solidaritätsaktion Stimme zu verschenken, SZ, 20 September 2013; Zukunft der EU: Sechs Milliarden Euro für Europas Jugend, SZ, 27 April 2013; Griechenland: Europarat fordert Hilfe für Flüchtlinge, FAZ, 24 January 2013; Des valeurs fondatrices sont en jeu à Bruxelles, Le Monde, 24 October 2013; Les règles de l'UE limitent l'accès au droit d'asile et défavorisent certains Etats abonnés, Le Monde, 9 October 2013; Migrants: "La France doit aider l'Italie", Le Figaro, 12 December 2013; La Grèce compte sur la «solidarité» de la France, Le Figaro, 4 February 2013; Grèce: les inégalités se creusent, Le Figaro, 3 May 2013.

Note 21. This issue answers Sternø's question "what is seen as the basis or foundation for solidarity?" Stjernø (2005).

Note 22.Union bancaire : un bon accord qui corrige les failles de la zone euro, Le Monde, 19 December 2013.

Note 23. Le rituel désuet et indigne du budget européen, Le Monde, 6 February 2013.

Note 24. Hollande reconnait des «impôts devenus trop lourds», Le Figaro, 31 December 2013.

Note 25. The agreement forecasts a 6.6 percent tax on deposits of less than $€ 100,000$ and 9.9 percent on those above that threshold, Le Monde, 18 March 2013.

Note 26. Bêtise et pingrerie de l'Europe au Sahel, Le Monde, 13 March 2013.

Note 27. M.S.S. was an interpreter who had fled Afghanistan in early 2008 after, as he claimed, an attempt was made on his life by the Taliban. His first entry to Europe was through Greece, where he was fingerprinted on arrival but did not claim asylum. He travelled through France and made his asylum claim in Belgium in February 2009, where his fingerprints, registered on the Eurodac system, showed that he had passed through Greece. Pursuant to Council Regulation EC 343/2003 ('the Dublin Regulation'), 2 an order was made in Belgium that he be returned to Greece. MSS lodged challenges to this decision with the Belgian Aliens Appeals Board but his applications were rejected for procedural reasons, and their merits were not considered. In parallel, in June 2009 he applied to the ECtHR to have his transfer suspended under Rule 39 (which enables the Court to make a provisional measures order). The Court refused to apply Rule 39, but informed the Greek Government that its decision was based on confidence that Greece would honour its obligations under the European Convention on Human Rights (ECHR) and comply with European Union (EU) legislation on asylum seekers. [see, Clayton, G. (2011). Asylum Seekers in Europe: M.S.S. v Belgium and Greece, Human Rights Law Review, Vol. 11 (No 4), 758-773; Council of Europe: European Court of Human Rights, M.S.S. v. Belgium and Greece, Application no. 30696/09, 21 January 2011]

Note 28. In Case C-411/10, Mr N.S., an Afghan national, came to the United Kingdom after travelling through, among other countries, Greece, where he was arrested in 2008. He was released by the Greek authorities four days later and ordered to leave Greece within 30 days. Mr N.S. did not make an asylum application. According to him, when he tried to leave Greece he was arrested by the police and expelled to Turkey, where he was detained in appalling conditions for two months. He states that he escaped from his place of detention in Turkey and travelled to the United Kingdom, where he arrived in January 2009 and lodged an asylum application. In July, Mr N.S. was informed that he would be transferred to Greece in August, under the 'Dublin II' Regulation. In legal proceedings then brought challenging that decision he alleged that there was a risk that his fundamental rights would be infringed were he to be sent back to Greece. The national court points out that asylum procedures in Greece have serious shortcomings, the proportion of asylum applications which are granted is extremely low, judicial remedies are inadequate and very difficult to access and the conditions for reception of 
asylum seekers also in adequate. (see, Court of Justice of the European Union, An Asylum Seeker may not be Transferred to a Member State Where he Risks being Subjected to Inhuman Treatment, Press release, No 140/11 Luxembourg, 21 December 2011)

Note 29. Goldner Lang, I. (2013). Is There Solidarity on Asylum and Migration in the EU?, Croatian Yearbook of European Law and Policy, Vol 9 (No 9) (December).

Note 30. Ibid., 13.

Note 31. Brussels, Repression ist der sichere Weg in den Tod, De Morgen, 8 October 2013.

Note 32. See Fernandes \& Rubio 2012.

Note 33. Germany, Wie Europa das Flüchtlingsproblem lösen will, SZ, 4 December 2013.

Note 34.Vienna, Boat people‘ auf Europa aufteilen, Die Presse, 12 August 2013.

Note 35. Germany, Flüchtlingsdrama vor Lampedusa Martin Schulz verlangt von Deutschland mehr Hilfe, SZ, 10 July 2013.

Note 36. 'L'ONU alerte l'UE sur les réfugiés syriens', Le Figaro, 22 November 2013.

Note 37. Йовчев: Съвсем скоро ще преминем нивото от 5000 бежанци, които можем да поемем 'Sofia solicits European aid', 24 Chasa,17 September 2013.

\section{Copyrights}

Copyright for this article is retained by the author(s), with first publication rights granted to the journal.

This is an open-access article distributed under the terms and conditions of the Creative Commons Attribution license (http://creativecommons.org/licenses/by/3.0/). 